\title{
THE AUTHORITARIAN ORIGINS OF WELL- ORGANIZED OPPOSITION PARTIES: THE RISE OF CHADEMA IN TANZANIA
}

\author{
Dan Paget*
}

\begin{abstract}
This article concerns the organizational expansion undertaken by the opposition party, Chadema, in Tanzania between 2003 and 2015. It argues that Chadema's extensive party-building enabled it to mobilize on the ground. These organizational developments, as much as elite action, underpinned recent changes in the party system and the opposition's improved showing in recent elections. Chadema established branches even though many of the prerequisite circumstances typically recognised in the literature were absent. This makes Chadema a deviant case and this deviance has implications for the historical institutionalist literature on party-building. This article complicates Rachel Riedl's account of state substitution. She links the incorporation or substitution of social actors to different paths of party system institutionalization. This article demonstrates that the character and consequences of state substitution depend upon the balance of power between state and social actors. It also builds on accounts by Adrienne LeBas and others that when social actors are strong, they can endow opposition parties with resources which make branch establishment possible, and when they are weak, they can only act as surrogate party branches. This article illustrates that when social actors are absent from partisan politics, parties have no way to organize except by founding green-site branches.
\end{abstract}

IT IS UNCOMMON FOR AN OPPOSITION party to establish local branches nation-wide in sub-Saharan Africa. African opposition parties are often poorly organized, ${ }^{1}$ and these

\footnotetext{
* Dan Paget (danjpaget@gmail.com) is a Teaching Fellow at the School of Oriental and African Studies. He recently completed his DPhil in Politics at the University of Oxford. Thanks go to Nic Cheeseman, George Roberts, Michaela Collord, Ole Therkidsen, Deogratias Munishi, two anonymous reviewers and the editors of African Affairs for their comments on earlier versions of this paper. Further thanks to all those who offered comments after conference and workshop presentations of this paper.

${ }^{1}$ Lise Rakner and Nicolas van de Walle, 'Opposition weakness in Africa', Journal of Democracy 20, 3 (2009), pp. 108-21.
} 
organizational shortcomings often take the form of poor local presence. ${ }^{2}$ This article is about when opposition parties in sub-Saharan Africa buck the trend; it makes an original contribution to the study of when they establish branches country-wide.

One opposition party that took this less trodden path is Chama cha demokrasia na maendeleo (Chadema), the Party of Democracy and Development. Between 2005 and 2015, Chadema's presidential vote share climbed from 6 percent to 40 percent. This was the best opposition party showing in Tanzania by a large margin, and constitutes a movement, however fleeting, from single-party dominance towards multi-party competition. Most accounts of this improvement in opposition fortunes have emphasised elite alliance and grand shifts in national debate. ${ }^{3}$ This article argues that the role of high politics, while undoubtedly important, has been exaggerated. Chadema's rise was also driven by a centrally-coordinated programme of branch-by-branch organization. These colossal efforts equipped Chadema with the apparatus to disseminate its message locally. Indeed, original survey evidence presented here suggests that Chadema's party machinery became much closer to rivalling the ruling party's than previously thought.

The Tanzanian case sheds light on historical institutionalist accounts of opposition partybuilding. Explanations of when opposition parties in Africa organize owe much to Rachel Riedl and Adrienne LeBas. ${ }^{4}$ Riedl traces party systems institutionalization back to postcolonial regimes' survival strategies. ${ }^{5}$ Where these regimes incorporate local elites, she argues, they in turn support the regime during subsequent democratic transition. This initiates a causal chain that ends in party system institutionalization and therefore opposition organization. Where, instead, the regime substitutes state officials for local elites, those marginalized elites support

\footnotetext{
${ }^{2}$ Vicky Randall and Lars Svåsand, 'Political parties and democratic consolidation in Africa', Democratization 9 , 3 (2002), pp. 30-52.

${ }^{3}$ Amanda Sperber, 'Tanzania set for tightest election in history', Foreign Policy October (2015); Sterling Roop and Keith Weghorst, 'The 2015 national elections in Tanzania', Electoral Studies 43 (2016), pp. 190-94; Machiko Tsubura, "Umoja ni ishindi (unity is victory)": Management of factionalism in the presidential nomination of Tanzania's dominant party in 2015', Journal of Eastern African Studies 12, 1 (2018), pp. 63-82.

${ }^{4}$ Adrienne LeBas, From protest to parties (Oxford University Press, Oxford, 2011); Rachel Riedl, Authoritarian origins of democratic party systems in Africa (Cambridge University Press, Cambridge, 2014).

${ }^{5}$ Riedl, Authoritarian origins of democratic party systems in Africa.
} 
the opposition during transition, which leads to inchoate party systems. LeBas connects opposition development to trade union incorporation by postcolonial regimes. Where unions are incorporated, they acquire the organizational networks and resources to support opposition party-building. ${ }^{6}$ Other scholars show that if social actors lack the wherewithal to support branch establishment, parties still engage them as ad hoc proxies, a surrogate form of local presence. ${ }^{7}$ Thus, social actors' character affects which modes of opposition party organization become feasible.

Tanzania's experience diverges from both of these theories, which makes it a deviant case. This article uses that deviance as a point of analytic leverage to extend Riedl's and LeBas' arguments. It contends that the character and outcomes of state-substitution are mediated by the balance of power between society and state. If the balance of forces favours local elites and civil associations during state substitution, they retain their mobilizational powers until democratic transition, which they control, as Riedl suggests. If instead they are weak, as they were in Tanzania, state substitution eliminates them or lastingly excludes them from partisan politics. Consequently, the regime controls democratic transition, the very outcome Riedl stipulates follows from incorporation.

This social flattening in Tanzania left unions and other local leaders alike unable to aid opposition party-building in the way that LeBas theorizes. However, political exclusion was so resounding that it rendered them unable to serve as viable ad hoc proxies either. This left opposition parties with only one organizational alternative: establishing branches without the help of social actors, a costly strategy which parties normally avoid. Therefore, weak social actors cannot help opposition parties organize, but can still serve as local proxies, while absent social actors leave opposition parties with no choice but to organize.

\footnotetext{
${ }^{6}$ LeBas, From protest to parties.

${ }^{7}$ Dominika Koter, 'King makers: Local leaders and ethnic politics in Africa', World Politics 65, 2 (2013), pp. 187-232.
} 
Nonetheless, organizing requires resources, and if social actors cannot supply them, parties must seek them elsewhere. Chadema began to establish branches once it raised significant private finance. This partly explains not only the timing of Chadema's emergence, but why it, rather than other opposition parties which were once more popular, won the mantle of opposition on the mainland. This article proposes that opposition party-building is more likely to occur in the absence of strong social actors if the finance sector is also liberalized. As Leonardo Arriola has argued, only then is capital free to support opposition politicians. ${ }^{8}$

The rise of Chadema in Tanzania is not only relevant to readers of Tanzanian politics. It is important for anyone that wishes to understand the historic institutionalist roots of opposition party development. Equally, it contains lessons for the students of both postsocialism and illiberal state-building in Africa.

This article proceeds as follows. The next section introduces the theories of Riedl and LeBas and proposes some modest extensions to them. The following section traces the political development of social actors in Tanzania and examines their mediating effect on the character of state substitution. The article then argues that this social landscape altered the feasible modes of opposition organization, and documents the scale and mode of Chadema's party-building efforts between 2003 and 2015. Finally, it presents evidence that these efforts fortified Chadema's ground campaign, and thereby contributed to its rise in popularity.

\section{Opposition party-building}

The literature identifies two modes by which parties extend their organisational presence geographically. In one, a party enlarges the total area in which it has local presence by founding branches. This form of 'green-site' branch establishment is the conventional form of party

\footnotetext{
${ }^{8}$ Leonardo Arriola, Multi-ethnic coalitions in Africa: Business financing of opposition election campaigns (Cambridge University Press, Cambridge, 2012).
} 
expansion elsewhere, but it is uncommon in sub-Saharan Africa. Instead, African parties typically expand organizationally by 'recruiting' or 'hiring' social actors, the delegation of party activities to a variety of 'local leaders' or intermediaries, often in exchange for money or favours. ${ }^{9}$ Anja Osei writes that "parties incorporate local big men as "shortcuts" to the rural population' ${ }^{10}$ Dominika Koter describes how parties 'subcontract mobilization to established local leaders'. ${ }^{11}$ Whichever mode of organization a party chooses, it still acquires local mobilizational capacity. In one case it is stored in party organs; in another, in extra-party networks. However, establishing branches binds mobilizational power to the party, while 'subcontracting' local elites does not. Therefore, modes of organization are significant; they have consequences for party institutionalization.

Past studies argue that incumbent dominance, ${ }^{12}$ particular ethnic configurations, ${ }^{13}$ and a military past ${ }^{14}$ drive parties to adopt one mode of organizing or another. However, the accounts of interest here focus on the role and character of social actors. 'Social actors' is used here as short-hand for an array of extra-party and extra-state actors with mobilizational capabilities. Across sub-Saharan Africa, this might include priests, imams, chiefs or kings, businessmen, big men, trade unions or civil associations. The term 'social actor' is broad enough to include both local and national actors, and it does not carry the ascriptions of role associated with 'civil society'.

For Riedl, the development of institutionalized party systems, and therefore, strong opposition parties, can be traced back to postcolonial regimes' survival strategies. She distinguishes between 1) the incorporation of local elites into state structures of administration

\footnotetext{
${ }^{9}$ Koter, 'King makers'.

${ }^{10}$ Anja Osei, 'Formal party organization and informal relations in African parties: Evidence from Ghana', Journal of Modern African Studies 54, 1 (2016), p. 41.

${ }^{11}$ Koter, 'King makers'.

${ }^{12}$ Riedl, Authoritarian origins of democratic party systems in Africa; LeBas, From protest to parties.

${ }^{13}$ Bruce Berman, Dickson Eyoh, and Will Kymlicka (eds), Ethnicity and democracy in Africa (James Curry, Oxford, 2004).

${ }^{14}$ Carrie Manning, 'Constructing opposition in Mozambique: Renamo as political party', Journal of Southern African Studies 24, 1 (1998), pp. 161-89.
} 
and distribution; and 2) the substitution of state agents for social actors in administration and distribution. ${ }^{15}$ She argues that at the moment of democratic transition, states which had incorporated local elites were strong enough to set rules that 'closed' the party system. Through several mechanisms, these rules and incumbent dominance drove party system institutionalization. In contrast, in regimes that pursued strategies of substitution, 'repressed traditional authorities and local socioeconomic elites remain socially important at the local level... The latent local elites remain an arsenal of enemies', biding their time in anticipation of a chance to reassert themselves. ${ }^{16}$ At regime transition, these local elites 'defected' to the opposition and helped it to take control and set rules that 'opened' the party system. This ultimately led to inchoate party systems. Through these causal chains, authoritarian regimes' strategies of survival affected democratic party system development.

LeBas advances an argument that is similar in form but distinct in particulars. She traces the development of 'strong' opposition parties back to the development of corporatist relations between postcolonial regimes and trade unions which make the latter organizationally powerful. After democratic transition, 'strong and centralized labor movements were available to provide mobilizing structures and a skeletal collective identity to new opposition parties' ${ }^{17}$ In a sense, trade unions provide an organizational 'host body' for opposition parties to inhabit and from which to produce multiple organs. LeBas writes that Zimbabwe's Movement for Democratic Change (MDC) 'piggybacked on the organizational structures of its component associations' ${ }^{18}$

LeBas's account rests on trade unions, but this is not a story that is specific to organized labour. She herself writes that 'the MDC also borrowed the organizational capacity of other

\footnotetext{
${ }^{15}$ Riedl, Authoritarian origins of democratic party systems in Africa.

${ }^{16}$ Ibid.

${ }^{17}$ Ibid. p. 48.

${ }^{18}$ Adrienne LeBas, 'Polarization as craft: Party formation and state violence in Zimbabwe', Comparative Politics 38,4 (2006), p. 426.
} 
members of the NCA [the National Constitutional Assembly]', notably churches, women's associations and student bodies. ${ }^{19}$ In principle, other social actors could render aid, and in cases such as Senegal and Ghana, they did. ${ }^{20}$ A synthesis of LeBas and the accounts of organizationby-subcontracting described above suggests that the modes of organization which parties choose depend upon the character of social actors. Only strong, nation-spanning social actors enable party organization by branch establishment, but weak social actors can still serve as extra-party surrogates.

This article uses the deviance of Tanzania to complicate Riedl and to advance an extension to LeBas. Tanzania shows that not all strategies of state substitution are alike. Some, like those described by Riedl, involve the temporary marginalisation of social actors, but the survival of those actors as 'latent elites'. Others, such as those found in Tanzania, involve destroying social actors' mobilizational power, or lastingly excluding them from partisan politics through the construction of laws and social norms. In former cases, social actors endure and are able to reenter partisan politics at the moment of democratic transition. In latter cases, they do not and cannot.

Whether state substitution culminates in temporarily marginalization, or instead extends to elimination and lasting exclusion, depends upon the relative power of social actors and state at independence. While Riedl's theory pertains to a domain of weak states, she is careful not to make assumptions about the character or strength of local elites. ${ }^{21}$ When the social actors are strong vis-à-vis the state, as they were in Riedl's cases, they are better placed to resist and moderate programmes of state substitution and remain mobilizationally strong while they are

\footnotetext{
${ }^{19}$ LeBas, From protest to parties, p. 185.

${ }^{20}$ Richard Vengroff and Michael Magala, 'Democratic reform, transition and consolidation: Evidence from Senegal's 2000 presidential election', The Journal of Modern African Studies 39, 1 (2001), pp. 129-62; Osei, 'Formal party organization and informal relations in African parties'; Riedl, Authoritarian origins of democratic party systems in Africa, p. 171 and p.182.

${ }^{21}$ Riedl, Authoritarian origins of democratic party systems in Africa, p. 105.
} 
politically marginalized. In contrast, when they are weak vis-à-vis the state, they are ill-placed to resist state substitution and they are likely to be diminished and lastingly excluded.

Leaving Riedl to one side, this article advances an extension to LeBas. When trade unions and other social actors are excluded from party politics, the option of expanding local presence by engaging proxies is foreclosed; if there are no social actors that are able and free to participate in party politics, parties cannot engage them as surrogates. This circumstance leaves parties with no means to expand organizationally except by founding branches, even though this option is only normally pursued when particularly wellresourced social actors can support it. Therefore, counterintuitively, while the presence of strong social actors encourages green-site party organization, so does their absence from party politics.

However, the absence or exclusion of social actors does not resolve how party-building is funded. The further contention of this article is that when social actors are excluded from politics, opposition parties can only build from the branch up if they can turn to some alternative pool of resources. One such alternative source is a liberalized financial sector. As Arriola argues, direct state control over the banking sector allows a ruling party to punish financiers of opposition parties by denying them credit. $^{22}$ Financial liberalization gives business autonomy to support opposition parties. He argues that business finance helps the opposition to resolve commitment problems. In contrast, this article contends that business provides an alternative source of finance which funds party-building. When advancing explanations of this sort, one must tread carefully through matters of structure and agency. The argument advanced here is not that capital automatically assists the opposition after financial liberalization. Instead, it argues that financial liberalization frees business people to

\footnotetext{
${ }^{22}$ Arriola, Multi-ethnic coalitions in Africa.
} 
do so. Even if just a fraction of them finance the opposition, financial liberalization leads to a rise in opposition funding.

\section{State-substitution in Tanzania}

Particular to the Tanzanian case are the trajectories of chiefly power. Across sub-Saharan Africa, European colonialists instituted systems of indirect rule. In doing so, they remade and privileged chieftaincies, often creating 'decentralised despots' with a 'clenched fist' of judicial, administrative, legislative and coercive powers. ${ }^{23}$ Equally, they actively participated in the imagination of ethnic identities and the hardening of ethnic boundaries from above and below. ${ }^{24}$ These colonially-constructed ethnic categories became the basis for popular political mobilization, and colonially-invented chiefs used their wealth and status as gatekeepers of ethnic peoples to become political entrepreneurs. ${ }^{25}$

In Tanganyika, many of these processes were at work, but they were arrested and impaired by peculiar historical circumstances. To begin with, most states and state-like bodies in precolonial Tanganyika served as poor bases for future power. John Iliffe describes that 'In 1800 Tanganyika was still frontier territory that was being penetrated by colonists from all directions' and that this abundance of land impeded state consolidation. ${ }^{26}$ The Shambaa, Hehe, Sangu, Haya and coastal trader polities, among others, were strong state-like bodies on the eve of colonial conquest. However, they constituted islands of political centralisation amid weak states and stateless peoples. ${ }^{27}$

\footnotetext{
${ }^{23}$ Mahmood Mamdani, Citizen and subject: Contemporary Africa and the history of late colonialism (Princeton University Press, Princeton, 1996).

${ }^{24}$ Eric Hobsbawm and Terence Ranger (eds), The invention of tradition (Cambridge University Press, Cambridge, 1983); Thomas Spear, 'Neo-traditionalism and the limits of invention in British colonial Africa', The Journal of African History 44, 1 (2003), pp. 3-27.

${ }^{25}$ Bruce Berman, 'Ethnicity, patronage and the African state: The politics of uncivil nationalism', African Affairs 97, 388 (1998), pp. 305-41.

${ }^{26}$ John Iliffe, A modern history of Tanganyika (Cambridge University Press, Cambridge, 1979), p. 8 and p. 9.

${ }^{27}$ Ibid.; Steven Feierman, The Shambaa Kingdom: A history (University of Wisconsin Press, Madison, 1974); Ralph Austen, Northwest Tanzania under German and British rule: Colonial policy and tribal politics, 18891939 (Yale University Press, New Haven, 1968).
} 
Indeed, scholarship suggests that many of these strongest polities in precolonial Tanganyika lacked either durability, power over their subjects, or territorial expanse in the nineteenth century. While Steven Feierman documents the enduring discursive influence of Kilinde chiefs, ${ }^{28}$ he also recognises that their kingdom's short existence involved cycles of expanding and contracting power. ${ }^{29}$ Iliffe writes that 'the Hehe state was thus an unsophisticated political system, entirely lacking bureaucratic principles'. ${ }^{30}$ Thomas Spear argues that 'Neither Meru nor Arusha had strongly centralized political systems'. ${ }^{31}$ As Gus Liebenow summarises, 'the Sukuma, Nyamwezi, Ha, Chagga, and other large groups each lacked centralized political authority'. ${ }^{32}$ Some nascent states may have been bastions of strength relative to others in Tanganyika, but they paled in comparison to many of their contemporaries elsewhere on the continent; there was no Zulu nation, Ashanti Empire, Fulani Emirs or Buganda Kingdom in Tanganyika with comparable authority, size and state-ness.

The precolonial landscape lastingly affected the repertoire of politically salient ethnic identities that Tanganyikan politicians could draw on. The British, determined to be faithful to 'indigenous institutions' in Tanganyika, however misconceived, privileged small identities and stymied the creation of larger ones. ${ }^{33}$ Even when they constructed agglomerate ethnicities, such as the Sukuma, ${ }^{34}$ these categories were still small in comparison to groups in other countries that constituted large pluralities or majorities of their citizens. ${ }^{35}$

\footnotetext{
${ }^{28}$ Steven Feiereman, Peasant intellectuals: Anthropology and history in Tanzania (University of Wisconsin Press, Madison, 1990).

${ }^{29}$ Feierman, The Shambaa Kingdom.

${ }^{30}$ Iliffe, A modern history of Tanganyika, p. 58.

31 Thomas Spear, 'Indirect rule, the politics of neo-traditionalism and the limits of invention in Tanzania', in Gregory Maddox and James Giblin (eds), In search of a nation: Histories of authority and dissidence in Tanzania (James Curry, Oxford, 2005), pp. 70-85, p. 73.

${ }^{32}$ Gus Liebenow, 'Responses to planned political change in a Tanganyika tribal group', American Political Science Review 50, 2 (1956), p. 447.

${ }^{33}$ Donald Cameron, 'Native administration in Tanganyika and Nigeria', Journal of the Royal African Society 36 , 145 (1937), p. 3 and p. 8.

${ }^{34}$ Ralph Tanner, 'The installation of Sukuma chiefs in Mwanza District, Tanganyika', African Studies 16, 4 (1957), pp. 197-209.

${ }^{35}$ Elliott Green, 'The political economy of nation formation in modern Tanzania: Explaining stability in the face of diversity', Commonwealth \& Comparative Politics 49, 2 (2011), pp. 223-44.
} 
Furthermore, chiefs themselves underwent a series of stresses and strains in the colonial period which impeded their efforts to accumulate authority and wealth. German conquest and pacification, the execution of the Maji Maji leaders, and the replacement of German-sponsored akidas by British-chosen chiefs undermined old rulers and destroyed some royal lineages entirely. ${ }^{36}$ Colonial rule disturbed chiefly authority almost as much as colonial conquest. British administrators introduced indirect rule in 1925, but diluted native authorities' powers from 1947 onwards. Justin Willis found that in effect, indirect rule was never introduced in some parts of Tanganyika. ${ }^{37}$ In these areas, native authorities never assumed control of native treasuries or native courts that would have provided opportunities for self-enrichment and the assertion of further authority. ${ }^{38}$ Simultaneously, British administrators directed native authorities to implement a catalogue of unpopular agricultural policies, which, Gören Hyden argues, chiefs lacked the legitimacy or coercive powers to enforce ${ }^{39}$ These episodes of chiefly over-assertion and peasant resistance are not only signs of chiefs' weakness. They constituted processes that further undermined their authority. Spear argues that 'Popular protests were almost always directed against the chiefs', ${ }^{40}$ and Hyden writes that 'Chagga chiefs were discredited as a result of their close collaboration with the British'. ${ }^{41}$

These elements are not uniquely Tanganyikan; customary elites were disturbed by colonial conquest and undermined as well as strengthened by colonial rule across sub-Saharan Africa. However, the processes that weakened chiefly power were particularly acute in Tanganyika. While some chiefs remained powerful in Tanganyika at independence, customary authorities

\footnotetext{
36 Austen, Northwest Tanzania under German and British rule; Goran Hyden, Beyond Ujamaa in Tanzania: Underdevelopment and an uncaptured peasantry (University of California Press, Berkeley, 1980); Iliffe, A modern history of Tanganyika, p. 200; Feierman, Peasant intellectuals.

37 Justin Willis, 'The administration of Bonde, 1920-60: A study of the implementation of indirect rule in Tanganyika', African Affairs 92, 366 (1993), pp. 53-67.

38 Leander Schneider, 'Colonial legacies and postcolonial authoritarianism in Tanzania: Connects and disconnects', African Studies Review 49, 1 (2013), p. 98.

${ }^{39}$ Hyden, Beyond Ujamaa in Tanzania, pp. 48-9 and p. 58.

40 Thomas Spear, 'Indirect rule'.

${ }^{41}$ Hyden, Beyond Ujamaa in Tanzania, p. 55.
} 
had been beset by a perfect storm that left them worse resourced, networked and legitimized than many of their African counterparts.

In the late colonial period, other social actors emerged that displayed mobilizational power that chiefs lacked. This included the Tanganyikan Federation of Labour (TFL) which by 1961 had 180,000 members. ${ }^{42}$ It also included the cooperative movement, which by 1959 had 325,000 members and had largely captured the production and marketing of major agricultural exports. ${ }^{43}$ Both were politically active. The unions had coordinated strikes over pay and independence through the late 1940s and 1950s. The cooperatives, for their part, used their wealth and voice to articulate local grievances and pursue political agendas. ${ }^{44}$ While cooperatives and unions were the strongest, other extra-party social actors were becoming politically capable too, notably networks of traders, religious leaders and civil servants, who formed the basis of Tanganyika African National Union's (TANU) nation-spanning network. Altogether, associational life in Tanganyika was vibrant and mobilizationally strong at the turn of independence.

In the one-party period, TANU dramatically altered the social landscape, beginning with the chiefs in 1962. It stripped them of property, revoked their powers over land, and supplanted their remaining administrative and judicial functions. Catherine Boone and Lydia Nyeme write that 'the government replaced most rural chiefs with direct state agents' ${ }^{45}$ TANU also usurped their legitimacy. Paul Bjerk writes that this local state transformation 'was also a governmental attempt to demonstrate its authority'. ${ }^{46}$ This was a case of state substitution par excellence. Chiefs' influence over their erstwhile subjects was further eroded by villagization, which

\footnotetext{
${ }^{42}$ Michael Lofchie, The political economy of Tanzania: Decline and recovery (University of Pennsylvania Press, Philadelphia, 2014).

${ }^{43}$ Andrew Coulson, Tanzania: A political economy (Oxford University Press, Oxford, 2013).

${ }^{44}$ Ibid.

45 Catherine Boone and Lydia Nyeme, 'Land institutions and political ethnicity in Africa: Evidence from Tanzania', Journal of Comparative Politics 48, 1 (2015), pp. 67-86.

${ }^{46}$ Paul Bjerk, Building a peaceful nation: Julius Nyerere and the establishment of sovereignty in Tanzania, 19601964 (University of Rochester Press, Rochester, 2015), p. 115.
} 
resettled over half of all Tanzanians and complicated claims over land or kinship. ${ }^{47}$ These policies eroded chiefs' remaining political power.

This campaign to eliminate chiefly power was driven by TANU's crystallising socialist ideology, Ujamaa na Kujitegemea, or 'Socialism and Self-reliance' ${ }^{48}$ Equally, it was informed by the calculus of political survival by a frontier state in the liberation wars. ${ }^{49}$ However, it was only feasible because in Elliot Green's words 'Tanzania has a weak state but an even weaker society' ${ }^{50}$ Elsewhere in sub-Saharan Africa, chiefs fended off assaults on their privileges from the state. In Ghana, for example, chiefs effectively resisted attempts by Kwame Nkrumah's government to 'destroy southern chieftaincy'. ${ }^{51}$ In Mali, chiefs were abolished, but officials continually depended upon them informally. ${ }^{52}$ Likewise, whatever local elites suffered in Benin and Zambia, Riedl argues that they were able to endure. ${ }^{53}$

In Tanganyika, by contrast, chiefs lacked the power to mount an effective opposition. The ethnic identities that they could draw upon were too narrow to serve as the organizing principles for nation-wide opposition. Equally, ethnic elite networks were too modest to serve as a basis for opposition coordination. Bjerk writes that 'Undermining chiefly power at independence was easy enough, since the chiefs were... widely unpopular'. ${ }^{54}$ As a consequence, TANU only encountered pockets of resistance. Hyden judges that 'By 1965, organized opposition [to land reform] in the rural areas had totally vanished'. ${ }^{5}$

\footnotetext{
${ }^{47}$ Boone and Nyeme, 'Land institutions'.

${ }^{48}$ Leander Schneider, 'Freedom and unfreedom in rural development: Julius Nyerere, Ujamaa Vijijini, and villagization', Canadian Journal of African Studies 38, 2 (2004), pp. 344-92.

${ }^{49}$ George Roberts, Politics, decolonisation, and the Cold War in Dar es Salaam c. 1965-72, (University of Warwick, unpublished PhD dissertation, 2016).

${ }^{50}$ Green, 'The political economy of nation formation in modern Tanzania.'

${ }^{51}$ Richard Rathbone, Nkrumah and the chiefs: The politics of chieftaincy in Ghana, 1951-60 (James Curry, Oxford, 2000), p. 8.

52 Baz Lecocq, 'From colonialism to Keita: Comparing pre- and post-independence regimes 1946-68', Mande Studies 5 (2003), pp. 29-47.

${ }^{53}$ Riedl, Authoritarian origins of democratic party systems in Africa, pp. 113-117.

${ }^{54}$ Bjerk, Building a peaceful nation, p. 123.

${ }^{55}$ Hyden, Beyond Ujamaa in Tanzania, p. 70.
} 
Most African revolutionary-centralizing regimes brokered arrangements with rival social actors recurrently, or reformed some while offering concessions to others. ${ }^{56}$ In contrast, the Tanzanian revolutionary-centralizing state turned from the just-defeated chiefs to confront other social actors from a position of strength. Therefore, it succeeded in reworking the social landscape more resoundingly. In part, TANU was fortunate. Organized labour became a belligerent political force and a natural locus of opposition in early independent Tanganyika. ${ }^{57}$ However, an impromptu army mutiny in 1964 created a pretext for repression of the trade unions, which were implicated indirectly in the mutiny. ${ }^{58}$ The TFL was disbanded and the National Union of Tanganyikan Workers (NUTA) was created in its place under the supervision of the Ministry of Labour. ${ }^{59}$ LeBas describes the integration of NUTA into the party in 1977 as 'only a formality'. ${ }^{60}$

Other associational life was similarly subdued or consumed by the state. Between 1966 and 1976, cooperatives were dissolved and their functions were transferred to state-owned companies and collective villages. ${ }^{61}$ By similar means, Islamic associations were incorporated into state-sponsored bodies and churches submitted to extensive state intervention. ${ }^{62}$ Civil servants were excluded from politics beyond the structures of the party; Hyden documents instances in which political activity by teachers was shut down in the $1960 \mathrm{~s} .{ }^{63}$ In sum, TANU

\footnotetext{
${ }^{56}$ James Coleman and Carl Rosberg, Political parties and national integration in tropical Africa (University of California Press, Berkley, 1964).

${ }^{57}$ James Brennan, 'The short history of political opposition and multi-party democracy in Tanganyika 1958-64', in Maddox and Giblin, In search of a nation, pp. 250-76.

${ }^{58}$ Bjerk, Building a peaceful nation, p. 150.

${ }^{59}$ Coulson, Tanzania: A political economy.

${ }^{60}$ LeBas, From protest to parties, p. 108.

${ }^{61}$ Coulson, Tanzania: A political economy.

${ }^{62}$ Bruce Heilman and Paul Kaiser, 'Religion, identity and politics in Tanzania', Third World Quarterly 23, 4 (2002), pp. 691-709; Frieder Ludwig, Church and state in Tanzania: Aspects of a changing relationship, 19611994 (Brill, Leiden, 1999).

${ }^{63}$ Goran Hyden, Political development in rural Tanzania: A West Lake study (East African Publishing House, Nairobi, 1969).
} 
prevented the formation of rival loci of power by stripping some groups of their power, excluding others from politics and folding others into the state apparatus. ${ }^{64}$

These assertions of bureaucratic power in Tanzania fit the category of state substitution neatly. However, in Riedl's cases, the affected actors endured at the periphery and returned with their mobilizational powers intact. In contrast, Tanzanian social actors lacked the wherewithal to either resist or endure state substitution. Consequently, TANU's state substitution extended to disbanding some social actors and excluding others. Accordingly, these social actors did not play the roles in democratic transition that their counterparts did elsewhere. Instead, democratic transition was initiated and controlled from above. ${ }^{65}$ Therefore, Tanzania strayed from the path that Riedl's theory prescribed. State substitution did not contribute to contested control of transition and the development of an inchoate party system. Instead, it contributed to regime-controlled transition and eventual party system institutionalization, the very outcomes which Riedl argues follow from incorporation.

\section{The rise of Chadema}

After the transition to multipartyism, the discursive basis of Tanzanian politics changed. Ujamaa was 'reconfigured' as a 'shared political language'. ${ }^{66}$ TANU, rechristened Chama cha mapinduzi (CCM) articulated a discourse of paternalism which 'asserts that the Tanzanian government is "father" to its citizen-children'. ${ }^{67} \mathrm{CCM}$ rhetorically constructed its seniority, provider-status and its legacy of peace. Thereby, it claimed that it alone was the heir to Nyerere. CCM's discursive power, state authoritarianism, and considerable wealth all contributed to its

\footnotetext{
${ }^{64}$ Mwesiga Baregu, 'Dynamics of Political Change in Tanzania', in Reflections on the Transition to Democracy in Tanzania, (REDET, Publication no 1, 1995), pp. 158-77; Hazel Gray, 'The political economy of grand corruption in Tanzania', African Affairs 114, 456 (2015), pp. 382-403.

65 Goran Hyden, 'Top-down democratization in Tanzania', Journal of Democracy 10, 4 (1999), pp. 142-55.

${ }^{66}$ Marie-Aude Fouéré, 'Julius Nyerere, Ujamaa and political morality in contemporary Tanzania', African Studies Review 57, 1 (2014), pp. 1-24.

${ }^{67}$ Kristin Phillips, 'Nyerere's ghost: Political filiation, paternal discipline, and the construction of legitimacy in Multiparty Tanzania', in Marie-Aude Fouéré (ed.) Remembering Julius Nyerere in Tanzania: History, memory, legacy (Mkuki na Nyota, Dar es Salaam, 2015), pp. 97-126.
} 
electoral dominance. With the exception of Zanzibar, where the Civic United Front consolidated support, initial opposition popularity in 1995 gave way to years of opposition drift.

Opposition fortunes gradually improved, in part because they sharpened their messages and in part, because a constellation of money and factionalism in CCM created a succession of grand corruption scandals. ${ }^{68}$ Chadema capitalised on these crises. It portrayed voters' grievances as the product of CCM malfeasance and collusion with foreign companies. ${ }^{69}$ MarieAude Fouéré writes that 'The significant electoral success of the Chadema opposition party... can be attributed partly to the capacity of its presidential candidate, Wilbroad Slaa, to shift the notion of filial descent from the incumbent President, Jakaya Kikwete, to himself' ${ }^{70}$

However, these changing electoral fortunes are also partly attributable to initial opposition disorganization and gradual opposition organization. Across Africa, trade unions, marabouts, churches, chiefs and other civil associations organized on behalf of parties. By contrast, after transition in Tanzania, social actors were conspicuous by their absence from partisan politics. ${ }^{71}$ Max Mmuya and Amon Chaligha describe cooperatives' political participation as 'nascent' and trade unions in particular as 'dormant'. They write that 'affiliation of interest groups to the political parties remain scant' ${ }^{72}$ Statutes continued to forbid the participation of religious organisations in politics, and both CCM local presence and inter-faith social ties kept those principles alive in social norms too. ${ }^{73}$ These laws and norms stifled the participation of religious actors in politics; those that supported politicians did so 'secretly' and 'quietly', or at great risk. ${ }^{74}$ This postsocialist legacy left some social actors mobilizationally diminished and others

\footnotetext{
${ }^{68}$ Gray, 'The political economy of grand corruption in Tanzania'.

${ }^{69}$ Felicitas Becker, 'Remembering Nyerere: political rhetoric and dissent in contemporary Tanzania', African Affairs 112, 447 (2013), pp. 238-261.

${ }^{70}$ Fouéré, 'Julius Nyerere, Ujamaa and political morality in contemporary Tanzania'.

${ }^{71}$ Tim Kelsall, 'Governance, democracy and recent political struggles in mainland Tanzania', Commonwealth \& Comparative Politics 41, 2 (2003), pp. 55-82.

${ }^{72}$ Mmuya and Chaligha, Political parties and democracy in Tanzania, pp. 140-1.

${ }^{73}$ Heilman and Kaiser, 'Religion, identity and politics in Tanzania'.

${ }^{74}$ Interview, Peter Msigwa, Dodoma, 13 June 2015.
} 
excluded by norms of political neutrality. ${ }^{75}$ This presented opposition parties with unusually acute dilemmas. Opposition parties could not rely on trade unions or other social actors to fund branch establishment, and equally they could not engage them as party proxies. The two common methods of opposition organizational expansion were foreclosed in Tanzania.

This left opposition parties with no alternative but to found green-site branches, but with no means to do so. This is evident in accounts of Chadema's early years. Beginning in 1992, Chadema's and other opposition parties' organizing efforts were arrested by limited funding. ${ }^{76}$ Chadema's revenue stream was so small and irregular that the party could often not pay for vehicles, accommodation or junior staff. ${ }^{77}$ Not only did the party secretariat lack funds, so did the candidates. One parliamentary candidate in the 1995 election, Tundu Lissu, recalled that 'I didn't have a car, I didn't have money' ${ }^{78}$

Chadema's funding problems were underpinned by the continued close state control of the economy and banking sector. Tanzania had among the most statist banking sectors in subSaharan Africa. Major reforms were made to the independence of privately owned commercial banks in the Banking and Financial Institutions Act of 1991, but the vast majority of commercial banking assets remained concentrated in state-owned banks. Boone judges that in spite of gradual market entry by small private banks, in 1997, Tanzania still had 'a statist banking system par excellence'. ${ }^{79}$ Anecdotal evidence suggests that businesspeople remained afraid that donations to the opposition would be punished by the state. Chadema's first chairman, Edwin Mtei, writes that 'in some instances, I did not even myself know the names

\footnotetext{
75 Aili Mari Tripp, 'Political reform in Tanzania: The struggle for associational autonomy', Comparative Politics 32, 2 (2000), pp. 191-214.

${ }^{76}$ Rose Shayo, 'Parties and political development in Tanzania' (EISA Research Report, Johannesburg, 2005); and Mmuya and Chaligha, Political parties and democracy in Tanzania.

${ }^{77}$ Edwin Mtei, From goatherd to governor: The autobiography of Edwin Mtei (Mkuki na Nyota, Dar es Salaam, 2009), p. 208.

${ }^{78}$ Interview, Tundu Lissu, Chadema Central Committee member, Dodoma, 13 June 2015.

${ }^{79}$ Catherine Boone, 'State, capital, and the politics of banking reform in sub-Saharan', Comparative Politics 37 , 4 (2005), pp. 401-20.
} 
of people who had given money to CHADEMA as they insisted on strict anonymity' ${ }^{80}$ Deogratias Munishi, Chadema's Head of Foreign Affairs, agreed that 'some time back, some businessmen could fear being aligned with opposition' ${ }^{81}$

However, liberalization of the banking sector quickened between 1998 and 2000, as the tworemaining large state-owned banks were privatized. ${ }^{82}$ By 2003, majority state-owned banks held just 4.25 percent of all assets in the commercial bank sector. Majority and minority stateowned banks together held just 37 percent of all such assets, ${ }^{83}$ a balance which remained steady until 2015. ${ }^{84}$ This was accompanied by a wider programme of economic liberalization and privatization. These changes meant that the state's ability to sanction businesspeople weakened.

Party-building in Chadema began in its youth wing in 2003 and across the party in 2007, soon after a new wave of capital moved to the party. Chadema receives some finance as a subsidy from government, but at every stage since its foundation in 1992, much of its funding has come from private donations. ${ }^{85}$ The scale of that private finance increased with the election of Freeman Mbowe as Chairman in 2004, who adopted the role of 'financier in chief'. ${ }^{86}$ Chadema Central Committee member Tundu Lissu remarked that 'one of the most important contributions that Chairman Mbowe has brought to Tanzanian politics is to make the opposition financially competitive... He brought his own money'. ${ }^{87}$ Moreover, Mbowe and other businessmen's support for the party provided a basis from which to borrow funds to smooth spending. Chadema Central Committee member Mwesiga Baregu explained that Chadema's

\footnotetext{
${ }^{80}$ Mtei, From goatherd to governor, p. 207.

${ }^{81}$ Phone Interview, Deogratias Munishi, Chadema Head of Foreign Affairs, Birmingham, 11 December 2017.

${ }^{82}$ Robert Cull and Connor Spreng, 'Pursuing efficiency while maintaining outreach: Bank privatization in Tanzania', Journal of Development Economics 94, 2 (2011), pp. 254-261.

${ }^{83}$ Director of Banking Supervision, Annual report, (Government of Tanzania, Dar es Salaam, 2004).

84 International Monetary Fund, 'United Republic of Tanzania: Selected issues - macrofinancial issues' (Washington DC, 2016).

${ }^{85}$ Mmuyu and Chaligha, Political parties and democracy in Tanzania.

${ }^{86}$ Interview, Tundu Lissu, Chadema Central Committee member, Dar es Salaam, 9 August 2015.

${ }^{87}$ Interview, Lissu, Dodoma.
} 
ability to borrow has benefited from 'his [Mbowe's] guarantee'. ${ }^{88}$ Lissu explained that 'After 2010, we started attracting...the professional set: lawyers, bankers, the people in the professions. Teachers. Doctors. We started getting people who had money' ${ }^{89}$ By 2015 , business contributions were ostentatious. Munishi recalled that 'we hosted three dinner fundraisings in Dar es Salaam... We booked it on television. Nationally broadcasted' ${ }^{90}$

Precisely what motivated businesspeople to give to Chadema is beyond the scope of this research and this article. In all likelihood, Chadema benefited from the lasting perceptions that its leaders were economically liberal, disenchantment with CCM among business elites, and the political exclusion of particular businesspeople. Throughout this period, CCM continued to enjoy the lion's share of business funding. However, crucial to this analysis is that CCM's ability to punish businesses that funded the opposition decreased as the banks were liberalized. Between 2003 and 2010, Chadema ran two operations in sequence. The first, run by the youth wing between 2003 and 2005, was called Chadema ni Tawi, or 'Chadema is the Branch'. ${ }^{91}$ The second, which ran between 2007 and 2010, was Operation Sangara. Both took a similar form. Chadema's most charismatic and famous leaders toured target areas into which the party hoped to expand, and convened rallies. 'We organize the crew. The national chairman, the secretarygeneral, everybody gets out of the office. We go to the field...At that time we take a convoy of ten to fifteen cars with Chadema flags. ${ }^{92}$ Munishi explained that 'the intention of Operation Sangara was to popularise the party'. ${ }^{93}$ Richard Shaba from Konrad Adenaeur Stiftung explained that 'in 2004, the major drive for Chadema was developing awareness. Making noise and shouting was very vital for them'. ${ }^{94}$ Simultaneously, operations Chadema ni Tawi and

\footnotetext{
${ }^{88}$ Interview, Mwesiga Baregu, Chadema Central Committee member, Dar es Salaam, 6 October 2015.

${ }^{89}$ Interview, Lissu, Dodoma.

${ }^{90}$ Phone Interview, Munishi.

${ }^{91}$ Interview, Benson Kigaila, Head of Chadema Directorate for Organization, Training and Zonal Administration, Dodoma, 16 June 2015.

${ }^{92}$ Interview, Deogratias Munishi, Chadema, Head of Foreign Affairs, Dar es Salaam, 30 April 2015.

${ }^{93}$ Ibid.

${ }^{94}$ Interview, Richard Shaba, Friedrich Ebert Stiftung, Dar es Salaam, 31 May 2015.
} 
Sangara were used to recruit members and ad hoc party structures. The head of Chadema's Directorate for Organization, Training and Zonal Administration Benson Kigaila explained that 'at the rally, you get maybe 300 members. After the rally, you stay somewhere with them to one side, give them the ABC's of learning the party. Thereafter you go. You leave them to organize themselves'. ${ }^{95}$ Chadema's former Secretary-General Wilbroad Slaa put it most directly: 'The mobilization team recruited more new party members through its public rallies. ${ }^{96}$ In this way, the large rallies of Chadema ni Tawi and Operation Sangara were used to equip the party with local organizational assets. They also raised further funds at rallies through petty donations.

In the elections of 2010, the Chadema presidential candidate vote share rose from 6 to 27 percent. Chadema benefited from shifting perceptions of CCM. The glamour that President Jakaya Kikwete brought to CCM upon his election in 2005 turned sour as his government became associated with corruption by a succession of events such as the Richmond Scandal. ${ }^{97}$ Equally, Chadema refined its messages about government corruption and support for foreign mining companies. However, Chadema was better able to capitalize on these events than other opposition parties. Its local branches harvested disaffected voters and amplified its message on the ground amid a chorus of CCM local voices.

Until 2011, the emphasis on mobilizing support had overlooked the scale of the task of developing a set of local party organs. As Shaba put it, 'they were creating awareness but... they couldn't harvest it'. ${ }^{98}$ Kigaila explained that 'in the year 2010, we had members. These members were not organized to form branches, to form msingi [foundations], to have leadership'. ${ }^{99}$ There seems to be consensus that the party members yielded few mobilizational

\footnotetext{
95 Interview, Kigaila.

${ }^{96}$ Wilbroad Slaa, 'Report by the Secretary General on the implementation of party activities' (Chadema National General Conference, Mlimani City Conference Hall, Dar es Salaam, 2014).

${ }^{97}$ Gray, 'The political economy of grand corruption in Tanzania'.

${ }^{98}$ Interview, Shaba

${ }^{99}$ Interview, Kigaila.
} 
benefits unless they were formed into local organs. Shaba said that 'in spite of all their efforts, it was still hanging at the district level. It wasn't quite there'. ${ }^{100}$

In response, Chadema changed tactics soon after the 2010 election. In 2012 it began a series of activities that went by various names, including Movement 4 Change (M4C) and Chadema ni Msingi or 'Chadema is the Foundation'. ${ }^{101}$ The scale of the ambition of this operation was vast. Slaa said that 'the thrust of the operation was to enable that the party set up 17,000 branches in which every village and neighbourhood has a party branch. To have 67,000 party primaries across the country and therefore to have 580,000 ten cell leaders' ${ }^{102}$ In that respect, M4C differed not just in the scale but in objective. Kigaila explained that 'Chadema ni Msingi was different from Operation Sangara because it was an organizational programme, a programme tried to network the party'. ${ }^{103}$ The purpose of Chadema ni Msingi was to 'to build the party right from the hamlet level' ${ }^{104}$ In this respect, Chadema mimicked CCM. It developed structures to mirror its rival's, a process of imitation which Riedl sets out theoretically. ${ }^{105}$

Unlike the previous efforts of the party, Chadema ni Msingi involved several programmes which ran in parallel. Firstly, the out-of-campaign-season rallies continued. Secondly, the party dispatched small teams of party organizers. They had two purposes: to oversee the establishment of new party organs where they were absent, and to convene new local leadership elections where the existing leadership had become dysfunctional. Where the party leadership convened rallies, organizers followed in their wake. 'They always leave one or two persons behind to make sure that if there is no leadership, a temporary leadership is nominated.' ${ }^{106}$

\footnotetext{
${ }^{100}$ Interview, Shaba.

${ }^{101}$ Msingi is the title of the lowest level of Chadema organs, equivalent to CCM's balozi.

102 Slaa, 'Report by the Secretary General.'

103 Interview, Kigaila.

${ }^{104}$ Interview, Munishi.

${ }^{105}$ Riedl, Authoritarian origins of democratic party systems in Africa.

${ }^{106}$ Interview, Shaba.
} 
Kigaila explained that 'these are the members here. Bring them together. You organize the party and you carry on... you supervise the selection of leaders'. 107

This process was followed by a nation-wide training programme. In 2012, with technical assistance from Konrad Adenaeur Stiftung and the Danish Conservative People's Party, whose considerable assistance began in the previous decade, Chadema ran a programme of 'training the trainers'. In total, Slaa estimated that between 2012 and 2014, Chadema trained 36,000 people. ${ }^{108}$ In all these efforts, social actors are notable by their absence. Chadema did not develop organizationally by either delegating local party activity to social actors, or by turning to social actors to resource branch establishment. Instead, it organized by establishing greensite branches, and turning to business to pay for it.

The outcome of these efforts was that Chadema developed a set of party structures that reached widely, but not uniformly, across the country. Slaa boasted 'we are now a party that is almost everywhere, and the results are very visible'. ${ }^{109}$ In 2014, Chadema had elected ward committees in 81.8 percent of all wards and 72 percent of all streets, villages and sub-villages, 16,359 in total. ${ }^{110}$ An examination of Chadema's finances over this period demonstrates that this party-building was only possible because of its improved funding. Between 2010 and 2014, Chadema spent 48 percent of its US\$5.7 million budget on party-building activities. ${ }^{111}$

However, more objective evidence can be found in the 2015 election ground campaign. Accepted wisdom in Tanzania is that CCM remains unambiguously better organized than Chadema. In the Mail and Guardian, CCM's January Makamba wrote that 'in Tanzania, few organizations can rival CCM's ability to mobilize citizens... CCM deploys its organizational

\footnotetext{
${ }^{107}$ Interview, Munishi.

${ }^{108}$ Interview, Wilbroad Slaa, former Chadema Secretary-General, Dar es Salaam, 5 June 2015.

${ }^{109}$ Interview, Slaa

${ }^{110}$ Slaa, 'Report by the Secretary General.'

${ }^{111}$ Expressed in 2016 US dollar terms. This figure was calculated taking average exchange rates from 2010 to 2014, and adjusting for inflation in dollars.
} 
prowess on the ground... it is organized in every street and village'. ${ }^{112}$ This view of CCM's organizational superiority is widely accepted, but original survey data challenges this assumption. Respondents to a custom-designed survey were asked how many times they were contacted 'face-to-face' by each party in the last month of the campaign. ${ }^{113}$ The results show that CCM canvassed 9.9 percent of respondents, equivalent to 2.25 million registered voters. ${ }^{114}$ Chadema, on the other hand, canvassed an estimated 11.8 percent of voters, equivalent to approximately 2.68 million registered voters. ${ }^{115}$ As these differences in means may be due to sampling error, these results should be interpreted as follows: one can conclude with confidence that in the last month of the 2015 campaign, Chadema canvassed at least almost as many voters as CCM, and the most likely state of affairs is that it canvassed more than CCM, despite the latter's reputation as an institutionalised dominant party. ${ }^{116}$

In light of Chadema's considerable reach and penetration, explanations of the 2015 election should be revised. Many have attributed the growth in opposition support between 2005 and 2015 to changes in high politics. Some stress the formation of a multi-party electoral coalition. Others emphasise the high-profile defection of former Prime Minister Edward Lowassa from CCM to Chadema, and his nomination as Chadema's presidential candidate. Others, described above, stress shifts in the rhetorical terrain. Accounts of the election outcome privilege the role

\footnotetext{
112 January Makamba, 'The crystal ball, 10 reasons why Tanzania's ruling party will retain power in Sunday's election', Mail and Guardian, 19 October 2015.

${ }^{113}$ Ipsos conducted a randomized, nationally representative, omnibus, face-to-face survey in September 2015 of 2,000 respondents, clustered in 200 primary sampling units across each of Tanzania's 30 regions. The author added private questions to that survey. A random subsample of these respondents was interviewed again by telephone in early November. The data presented here is from this second round. The re-contact rate was 82 percent and the size of this subsample was 1,000. For further examination of this data, see Dan Paget, The rallyintensive ground campaign: Electioneering and party adaptation in Tanzania, (University of Oxford, unpublished PhD dissertation, 2018).

114 The standard error is 1.0 percent. These figures are weighted by age, gender and region to ensure that it is nationally representative, and in particular, to correct the overrepresentation of Zanzibar in the survey sample. The unweighted figure is 11.6.

115 The standard error is 1.2 percent. Weighted as above. The unweighted figure is 11.5 , so without weighting, the point estimates are almost identical.

116 Yonatan Morse, 'Party matters: The institutional origins of competitive hegemony in Tanzania', Democratization 21, 4 (2014), pp. 655-77; Randall and Svåsand, 'Political parties and democratic consolidation in Africa'.
} 
of all these changes. ${ }^{117}$ Allusions were made to other countries where splits in the ruling party led to opposition gains. ${ }^{118}$ The East African ran with the headline 'New political alliances threaten Tanzania's CCM' ${ }^{119}$ To counter-balance these explanations, this article contends that accounts of the rise in Chadema's popularity should focus on low-level organization more, and high-level politics less.

Parties' messages, however potent, can only sway voters if they are imparted to them. A significant portion of Tanzania's political conversation takes place on its 'pavement radio'. ${ }^{120}$ Accordingly, Tanzanian struggles of political communication are fought not only in the air campaign, but the ground campaign. Chadema became popular for many reasons. It honed its rhetoric, which the changing context made increasingly potent. The formation of an opposition coalition unified disparate parties' efforts. CCM defections fortified Chadema with money, powerful symbolic capital, and charismatic candidates. However, Chadema was able to press home these advantages because its ground organisation amplified its voice. Its party-building provided an apparatus that carried these messages and multiplied exposure to them. The parity in canvassing rates shows its success in this aspect of ground campaigning.

\section{Conclusion}

Chadema's case is a deviant one. It organised even though many of the prerequisite circumstances privileged in the historical institutionalist literature were absent. This article uses that deviance to build upon Riedl and LeBas. In doing so, it constructs a new path-dependent explanation of opposition organization. It illustrates how much strategies of state substitution differed in Africa. It suggests that when state substitution is done from a position of strength,

\footnotetext{
117 Sperber, 'Tanzania set for tightest election in history'; Roop and Weghorst, 'The 2015 national elections in Tanzania'; Tsubura "'Umoja ni ushindi (unity is victory)"”.

118 Mail and Guardian, 'Tanzania election race takes a leaf from Senegal, Nigeria and Kenya; unexpectedly hots up', 4 August 2015.

119 Yasuyoshi Chiba, 'New political alliances threaten Tanzania's CCM', The East African, 22 August 2015.

${ }^{120}$ Stephen Ellis, 'Tuning in to pavement radio', African Affairs 88, 352 (1989), pp. 321-330.
} 
social actors may not be temporarily marginalized, but may instead be lastingly expelled from party politics or stripped of their powers altogether.

Social flattening of this kind renders local elites and civil associations alike unable to serve as surrogates for local presence. Under these circumstances, the only method of organizational advancement available to opposition parties is to establish branches from scratch. However, opposition parties can only undertake this costly effort with the support of private finance.

The Tanzanian case is instructive. While Tanzania is often treated as exceptional, similar centralizing-revolutionary programmes were carried out in communist Benin and socialist Guinea. ${ }^{121}$ Equally, there are contemporary parallels to Tanzania's social engineering in the experiences of Rwanda and Ethiopia. ${ }^{122}$ Studies of opposition party-building in these countries in the future should consider the lessons to be learned from the Tanzanian postsocialist experience. This article also reveals much about the nature of African opposition organization. It documents organizational development which is not primarily about the professionalization of party organs, but the proliferation of them.

Lastly, this article also documents a significant contemporary development in Tanzania's party politics. It shows that between 2003 and 2015, Chadema established a hierarchy of party organs which extended its local presence across much of Tanzania. The number of branches formed and the balance of canvassing between the main parties show that Chadema's organizational transformation took place not only on paper, but on the ground. This was an important shift in Tanzania's party system, even if it transpires to be ultimately short-lived. Chadema's party-building shortened CCM's organizational advantage. That in turn had ramifications for Tanzania's politics which reach far beyond the election of $2015 .{ }^{123}$

${ }^{121}$ Dominika Koter, Beyond ethnic politics in Africa (Cambridge University Press, Cambridge, 2016).

${ }^{122}$ Scott Straus and Lars Waldorf (eds), Remaking Rwanda: State building and human rights after mass violence (University of Wisconsin Press, Madison, 2011); John Abbink and Tobias Hagmann (eds), Reconfiguring Ethiopia: The politics of authoritarian reform (Routledge, Abingdon, 2013).

${ }^{123}$ Dan Paget, 'Tanzania: Shrinking space and opposition protest', Journal of Democracy 28, 3 (2017), pp. 15367. 
